DOI 10.37882/2223-2982.2021.06.32

\title{
РУСИЗМЫ В СОВРЕМЕННОМ АНГЛОЯЗЫЧНОМ СЛЕНГЕ
}

\section{RUSSICISMS IN MODERN ENGLISH SLANG \\ I. Puchkova}

Summary: The article describes russicisms in modern English slang. Special attention is given words denoting Russian realities. Their types are pointed out and mechanisms of their transformation into slang words are considered. Conclusions are made concerning the slang meaning of russicisms as the reflection of the image of Russia in the worldview of the bearers of the Anglophone culture.

Keywords: slang, the English language, borrowings, russicisms, semantic changes.
Пучкова Ирина Николаевна

К.филол.н., доцент, Московский городской педагогический университет

irenep@yandex.ru

Аннотация: В статье описываются русизмы в современном английском сленге. Особое внимание уделяется русизмам-реалиям. Выделяются их виды и рассматривается механизмы их трансформации в сленгизмы. Делаются выводы 0 том, как сленговое значение русизмов отражает представление 0 России в картине мира носителей англоязычной культуры.

Ключевые слова: сленг, английский язык, заимствования, русизмы, семантические изменения.

ге трансформации подвергается значение таких групп русизмов, как реалии-этнонимы, реалии-топонимы, реалии-антропонимы, культурно-исторические и бытовые реалии.

Этноним Russian (русский) существует в английском языке с 30x годов XV века. В современном английском сленге наблюдается расширение значение этого слова, поскольку оно все чаще употребляется применительно к любому лицу славянской национальности (Tony: Hey you see that Russian guy over there? Toby: The one speaking Polish? He's not Russian I don't think. Tony: Yeah, the Russian one).

Лексема Russian входит в состав ряда сленговых выражений: Russian style, Russian coffee, Russian bias. Остановимся на них подробнее.

Выражение Russian style многозначно. Некоторыми носителями английского языка подмечена необычная для них бытовая привычка русских добавлять соль в салат перед тем, как его перемешать, поэтому такой способ приготовления называется русским. Выражение Russian style употребляется в значении «нечто дешевое и низкокачественное» ("my car broke down» «Pfft, its russianstyle»), что отражает расхожее представление о России как о стране с низко развитой экономикой. Аналогичное значение (нежелательный о ситуации или некачественный о вещи) имеет и прилагательное Soviet (советский)(this Dominoes pizza is pretty soviet).

Среди носителей английского языка сложилось мнение, что русские склонны к злоупотреблению алкоголем, что нашло отражение в сленговом выражении Russian coffee (бутылка водки с добавлением небольшого количества свежесваренного кофе)

Выражение Russian bias (русский уклон) встречается

Анализ материала показал, что в англоязычном слен- 
в сленге англоязычных геймеров. Так называют себя те участники платформенной военной онлайн-игры War Thunder (игра посвящена боевой авиации, бронетехнике и флоту со времен Второй мировой войны до наших дней), которые играют на советской боевой технике, так же называется и сама советская техника. Фраза «Russian bias!» используется проигравшими игроками в знак признания собственного поражения, ее подтекст заключается в том, что советская техника слишком сильна, чтобы с ней справиться.

Лексема Rusky/Ruski/Ruskies/Ruskie вошла в английский язык в XIX веке после Крымской войны. Как известно, Великобритания и Россия были в этом конфликте противоборствующими сторонами, поэтому данный этноним приобрел в английском языке пейоративный оттенок, поскольку ассоциировался с образом врага. Частотность употребления слова Rusky возрастает во второй половине XX века в США, что связано с притоком эмигрантов из СССР, а позднее - из стран СНГ. Выходцы из бывшего СССР, оказавшись в США, часто выполняли низкоквалифицированную работу, либо, по мнению местного населения, становились членами «русской мафии», поэтому негативная оценочная коннотация данного слова сохраняется в американском варианте английского языка. В настоящее время данный русизм может употребляться как в отрицательном (Nuke those damn Ruskies), так и в нейтральном или положительном контексте (We all know how much guts the Average Ruskie's got). Интересно, что в русском языке слово «Русские» - это существительное во множественном числе, в английском языке оно может употребляться и когда речь идет об одном человеке (he is a ruskie).

Реалия-антропоним Stalin используется в современном англоязычном сленге как нарицательное существительное в переносном значении «глупый человек с высоким самомнением» (don't be such a Stalin!). В Интернет-дискурсе возник также глагол to stalin, образованный от существительного при помощи конверсии. «редактировать или исправлять задним числом статусы, фотографии, комментарии и посты в интернете»

I worte 'write' 'right in my Facebook status but I realised I could Stalin it before anyone but Josh noticed.

В основе значения сленгового глагола прослеживается отсылка к распространенной в СССР при И.В. Сталине практике ретуширования официальных снимков для того, чтобы уничтожить изображения первых лиц государства, подвергшихся репрессиям.

Антропоним Ivan впервые зарегистрирован в английском языке в 70 годы XIX века. В период Крымской войны это распространенное в России мужское имя использовалось англичанами как прозвище русского сол- дата, а позднее - любого русского. Пренебрежительный оттенок, вызывающий ассоциации с образом недалекого человека, сохраняется и в производной лексеме современном сленговом слове ivanism, образованном от основы ivan- при помощи суффикса абстрактного существительного -ism. Слово ivanism имеет несколько значений: 1. Неубедительный или глупый ответ в ходе дискуссии на интернет-форуме или в блоге, 2 Ненадежный пароль, который легко взломать (this code is full of ivanisms), 3. Глупость, чушь (используется в качестве аналога выражения «foot in mouth»). Как видно, во всех значениях этого слова присутствует негативный оценочный компонент, вытекающий из стереотипного представления о русских как о людях, не обладающих высокими интеллектуальными способностями.

Существительное Bolshevik появилось в английском языке после 1917 года и является политико-исторической реалией-русизмом. По данным этимологического словаря английского языка, первоначальное значение этого слова - «Russian radical socialist of the revolutionary period" [7], (русский социалист радикального толка в эпоху революции). После того, как большевики пришли к власти в России, значение слова Bolshevik в английском языке стало шире, им стали называть сначала русских коммунистов, а затем всех, кто разделял коммунистические идеи вне зависимости от их национальной принадлежности. В современном англоязычном сленге лексема bolshevik и ее производная Bolshevism употребляются в качестве эвфемизма вместо bullshit, поскольку данные лексемы имеют сходный набор звуков. На игре слов и созвучии основан и сленгизм Bowlshevick, который в дискурсе наркозависимых используется как синоним слова bowl-трубка для марихуаны.

В выражении Bolshevik marketing (агрессивная маркетинговая компания, когда производитель навязывает свой товар потребителям, не учитывая их желаний) русизм bolshevik вызывает в сознании носителей английского языка ассоциации с экономической политикой СССР, когда правительство решало за население, какой товар и в каком количестве им нужен. Таким образом, выражение приобретает явный пейоративный оттенок, вызывая ассоциации с тоталитаризмом, отсутствием свободы выбора и пренебрежением к интересам личности.

Среди русизмов в англоязычном сленге отмечены и реалии-топонимы. Хороним Siberia (Сибирь), используемый как прилагательное со значением «холодный» (It's going to be-3 degrees today - Wow! It's Siberia today), образован в результате метонимического переноса, поскольку в сознании носителей англоскасонской культуры Сибирь ассоциируется с холодом. Кроме того, данный русизм зафиксирован и в криминальном жаргоне, поскольку словом Syberia называется помещение для содержания задержанных под стражей в суде г. Фила- 
дельфия. Шутливо-ироничное значение данного слова возникло на основе метафорического переноса (низкая температура воздуха в помещении подобна сибирским холодам). Еще одно сленговое значение топонима Siberia - «неудобное, далекое от входа место на парковке»: (Professor: You're late for class. Student: Sorry, I had to park in Siberia).

Хороним Crimea стал широко известен в англоязычном мире после известных событий 2014 года. Как известно, воссоединение Крыма и России вызвало негативную реакцию на Западе и преподносилось в иностранных СМИ не иначе, как «захват» и «аннексия». Данный факт послужил основанием того, что в молодежном сленге возник глагол to Crimea, значение которого - постепенно и незаметно занимать чужую территорию. Так, если девушка перевозит в квартиру партнера свои туалетные принадлежности, предметы одежды и прочие вещи, но отрицает, что фактически там проживает, то ее действия можно назвать глаголом to Crimea, а его результат - отглагольным существительным Crimeaing: Sara told Tim it was just easier to have a toothbrush at his place, but it was all part of her plan to Crimea his place.

В 2014 году в Сочи проводились Зимние Олимпийские игры. Перед этим в соцсетях активно обсуждались недоделки на олимпийских объектах и выкладывались их снимки, что дало повод англоязычным пользователям интернета использовать астиноним Sochi в метафорическом значении «нечто не работающее нормально» или как синоним существительного «гетто» (Your tap water is yellow...you'd say that's Sochi!).

Урбаноним Kremlin зарегистрирован в английских источниках XVII-XVIII века. В них это слово употреблялось в прямом первоначальном значении «укрепленное место любого русского города, прежде всего, Москвы» [7]. После 1933 года данный русизм используется и в метонимическом значении «правительство СССР» [7], а во второй половине 2010-х годов в дискурсе англоязычных блогеров отмечено употребление данной лексемы в метонимическом значении «интернет-тролль, финансируемый российскими властями» (Kremlins are active today in this forum!).

Русская реалия Kremlin входит в состав целого ряда сленговых выражений. Одно из них - Kremlin's Law - обозначает явление, при котором в ходе онлайн-обсуждения кого-то из участников обязательно назовут русским ботом или «агентом на службе Кремля». Источником словосочетания Kremlin's Law послужило понятие Godwin's Law (закон Годвина). Американский юрист и писатель Майк Годвин подметил, что по мере нарастания дискуссии вероятность сравнения с нацистами или Гитлером приближается к единице. Выражение Kremlin's Law, образованное по аналогии с вышеупомянутым термином
Godwin's Law, возникает в англоязычном Интернет-дискурсе в 2020 году под влиянием расхожих мифов о «русских хакерах» и их вмешательстве во все сферы жизни западных стран.

Интересно отметить, что Гарвардский университет имеет шутливое прозвище Kremlin on the Charles. Оно объясняется тем, что Гарвард традиционно отличался либеральным отношением к прокоммунистическим взглядам даже во времена маккартизма, когда во всей стране существовал запрет на профессию для коммунистов и им сочувствующих.

Основа kremlin стала производящей для существительного Kremlinology - изучение и анализ российской политики, а ранее - политики СССР. В середине двухтысячных годов можно наблюдать употребление термина Kremlinology вне российского контекста в значении «изучение или расследование того, что происходит в некой закрытой организации или компании»: In the article the Times applied a little Kremlinology to investigate why Windows Vista had gone so horribly wrong.

Существительное Kossack (активный пользователь сайта DailyKos) вызывает явные ассоциации с русской культурно-исторической реалией Cossack (казак), абсолютно совпадая с последним в произношении и отличаясь лишь одной буквой в написании. Сайт DailyKos opганизован сторонниками демократической партии США. Компонент KOS в его названии - аббревиатура девиза Keep Obama Senator. Дело в том, что во время предвыборной кампании 2008 года радикально настроенные демократы считали, что у Барака Обамы недостаточно опыта для того, чтобы быть президентом США, и ему следует оставаться на посту сенатора, отсюда появился девиз, который лег в основу названия сайта. Пользователи DailyKos отличаются ультрарадикальными левыми взглядами и весьма активны в своей деятельности, что и дало повод для их шутливо-ироничного сравнения с воинственными казаками.

Русская культурно-бытовая реалия borscht (борщ) является частью наименования Borscht Belt. Это неофициальное, шутливое название летних курортов и отелей, расположенных в северной части штата НьюЙорк в США. Из-за близости к Нью-Йорку и дешевизны земли на рубеже XIX - XX веков этот район был облюбован еврейскими иммигрантами из Восточной Европы, которые начали строить там недорогие пансионаты. Популярным блюдом, подаваемым к столу в этих пансионатах, был борщ, отсюда и произошло название «Борщовый Пояс».

Итак, анализ сленговых слов и выражений русскоязычного происхождения показал, что с тематической точки зрения они представлены русскими реалиями. 
Среди них можно выделить реалии-этнонимы, реалиитопонимы, реалии-антропонимы, культурно-бытовые и культурно-исторические реалии. Включаясь в англоязычный дискурс через метафорическое или метонимическое переосмысление значения, расширение значения, а также благодаря созвучию с английскими словами, русизмы приобретают, как правило, негатив- ную оценочную коннотацию, что связано с негативным образом России, создаваемым западными СМИ. Носители английского языка употребляют русизмы в сленговом значении с целью продемонстрировать свое остроумие, нестандартный подход к описанию фактов и ситуаций, а также эмоциональное отношение к различным явлениям действительности.

\section{ЛИТЕРАТУРА}

1. Ефремова Т.Ф. Новый толково-словообразовательный словарь русского языка. в 2 т. М.: Русский язык, 2000. 1209 с. [элект. версия]: URL: https://www. efremova.info/word/sleng.html\#.Ylv6lismzlU (дата обращения: 30.04.2021)

2. Лингвистический энциклопедический словарь: [элект. версия]: URL: https://rus-lingvist-dict.slovaronline.com/1004-сленг (дата 0бращения: 30.04.2021)

3. Мизюрина Т.В. Определение и общие характеристики понятия «сленг», его роль в языке и культуре современной России // Вестник Челябинского государственного университета. 2013. № 1 (292). Филология. Искусствоведение. Вып. 73. С. 106-111.

4. Митчелл П.Д., Белов Д.Н. Британский военный сленг: влияние Первой мировой войны // Вестник Тамбовского государственного университета. Серия Гуманитарные науки. 2016. Т.21, вып. 7-8. С.15-22

5. Ожегов С.И., Шведова Н.Ю. Толковый словарь русского языка. М.: Азбуковник, 1999. 944 с.

6. Павленко В.Г. Особенности употребления молодежного сленга в современном русском и английском языках // Гуманитарные научные исследования. 2017. № 2 [элект. версия]: URL: https://human.snauka.ru/2017/02/21393 (дата обращения: 12.04.2021).

7. Onine Etymology Dictionary URL: https://www.etymonline.com/ (дата обращения: 30.04.2021)

8. Urban dictionary. Онлайн словарь англоязычного сленга. URL: https://www.urbandictionary.com/ (дата обращения: 30.05.2021)

\section{( Пучкова Ирина Николаевна (irenep@yandex.ru).}

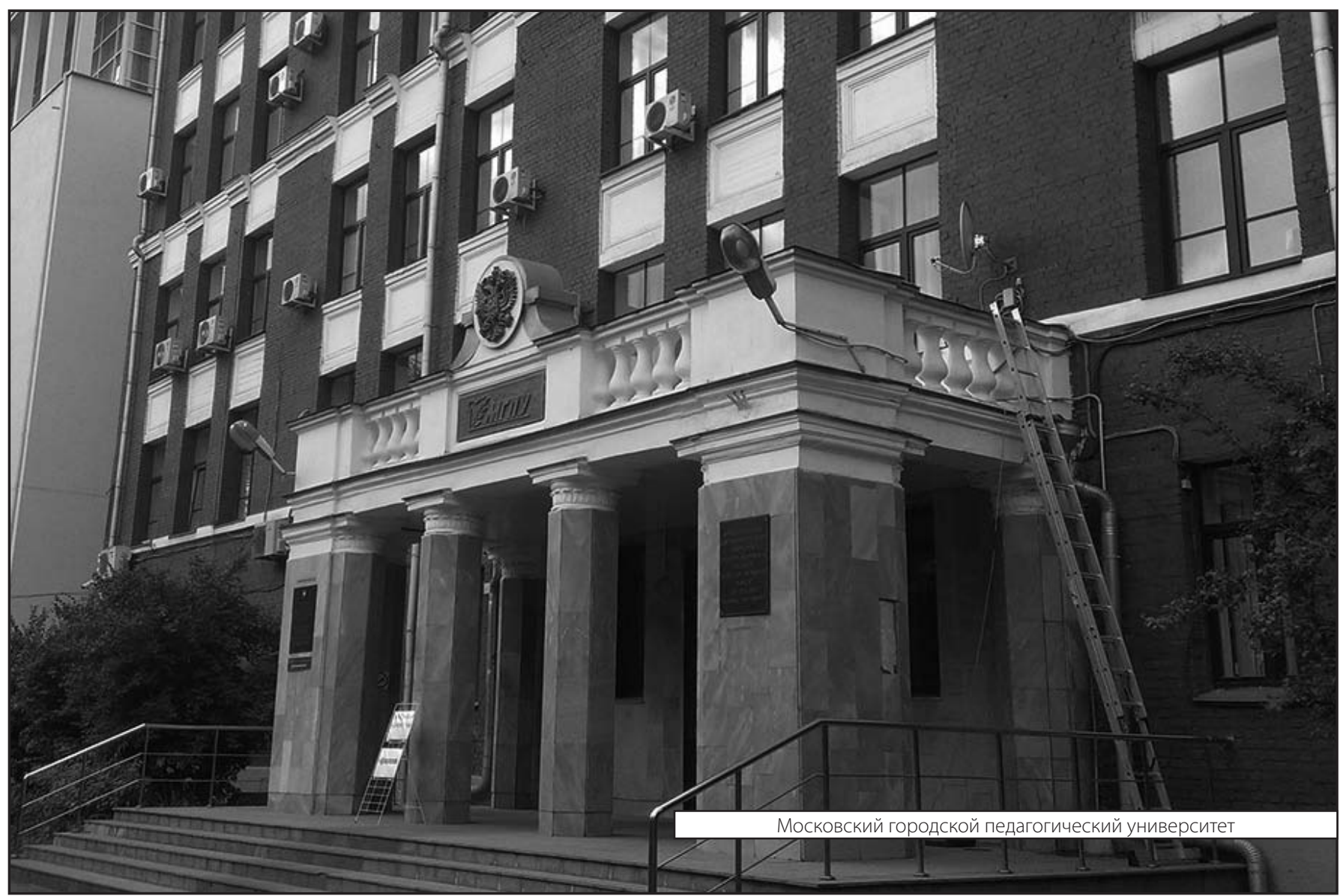

